\title{
Evaluation of Hydrogel and Salicylic Acid Application Effect on Yield, Quality, Economics and Water-Use Efficiency of Indian Mustard (Brassica juncea) in Restricted Irrigation Condition of S-E Rajasthan
}

\author{
B. S. Meena ${ }^{1 *}$, R. S. Narolia ${ }^{1}$, L. K. Meena ${ }^{2}$, K. C. Meena ${ }^{2}$ and S. N. Meena ${ }^{1}$ \\ ${ }^{1}$ Agricultural Research Station, Ummedganj, Agriculture University, \\ Kota-324001 (Rajasthan, India) \\ ${ }^{2}$ College of Agriculture, Kota, Rajasthan, India \\ *Corresponding author
}

\begin{abstract}
A B S T R A C T
A field experiment was conducted at Agricultural Research Station, Kota during the rabi seasons of 2017-18, 2018-19 and 2019-20 to evaluate effective dose of hydrogel and salicylic acid for increasing the productivity, quality and water-use efficiency of Indian mustard in restricted irrigation condition of S-E Rajasthan. The experiment consisting of 12 treatment combinations, viz. $\mathrm{T}_{1}$ :control, $\mathrm{T}_{2}$ :hydrogel $2.5 \mathrm{~kg} / \mathrm{ha}, \mathrm{T}_{3}$ : hydrogel $5 \mathrm{~kg} / \mathrm{ha}, \mathrm{T}_{4}$ : salicylic acid (SA) $100 \mathrm{ppm}$ at flowering (fl) and siliqua formation (sf), $\mathrm{T}_{5}: \mathrm{SA} 200 \mathrm{ppm}$ at $\mathrm{fl}$ and sf, $\mathrm{T}_{6}:$ hydrogel $2.5 \mathrm{~kg} / \mathrm{ha}+\mathrm{SA} 100 \mathrm{ppm}$ at fl and sf, $\mathrm{T}_{7}:$ hydrogel $2.5 \mathrm{~kg} / \mathrm{ha}+\mathrm{SA} 200 \mathrm{ppm}$ at fl and sf, $\mathrm{T}_{8}$ :hydrogel $5 \mathrm{~kg} / \mathrm{ha}+\mathrm{SA}$ $100 \mathrm{ppm}$ at $\mathrm{fl}$ and sf, $\mathrm{T}_{9}$ : hydrogel $5 \mathrm{~kg} / \mathrm{ha}+\mathrm{SA} 200 \mathrm{ppm}$ at fl and sf, $\mathrm{T}_{10}$ :Two irrigation at pre-flowering and siliqua development, $\mathrm{T}_{11}$ : hydrogel $2.5 \mathrm{~kg} / \mathrm{ha}+\mathrm{SA} 100 \mathrm{ppm}$ at fl and $\mathrm{T}_{12}$ :hydrogel $2.5 \mathrm{~kg} / \mathrm{ha}+\mathrm{SA} 200 \mathrm{ppm}$ at fl were laid out in randomized block design with three replications. Among treatment combinations, application of hydrogel $5 \mathrm{~kg} / \mathrm{ha}$ with two spray of salicylic acid $200 \mathrm{ppm}$ at flowering and siliqua formation stage significantly increased plant height $(222.40 \mathrm{~cm})$, dry matter/plant $(62.20 \mathrm{~g})$, branches/plant ( 16.33), siliquae /plant (236.67), seeds/ siliqua (16.23), 1000-seed weight (5.47 g), seed yield (2651.89 kg/ha), oil content (38.95\%) and oil yield $(1032.91 \mathrm{~kg} / \mathrm{ha})$, protein content $(21.07 \%)$, gross return ( $₹ 1,13,404 / \mathrm{ha})$, net return ( $₹ 82,818 / \mathrm{ha})$ and soil moisture retention $(13.70 \%)$ over $\mathrm{T}_{1}, \mathrm{~T}_{4}, \mathrm{~T}_{5}$ and $\mathrm{T}_{2}$ and at par with rest of treatments. While, the highest wateruse efficiency $(12.83 \mathrm{~kg} / \mathrm{ha}-\mathrm{mm})$ was recorded under the same treatment but it was significantly superior over $\mathrm{T}_{1}$, $\mathrm{T}_{2}, \mathrm{~T}_{3}, \mathrm{~T}_{4}, \mathrm{~T}_{5}$ and $\mathrm{T}_{10}$ and on par with rest of treatments. Whereas significantly higher $\mathrm{B}: \mathrm{C}$ ratio (3.46) recorded in irrigation treatment over all the other treatments. Furthermore significantly highest improvement in growth, yield attributes and economics was recorded under irrigation treatment applied at pre-flowering and siliqua formation stage over $\mathrm{T}_{1}$ and alone application of hydrogel and SA. Thus, the result showed that application of hydrogel either 2.5 or $5 \mathrm{~kg} / \mathrm{ha}$ with two spray of SA $200 \mathrm{ppm}$ at flowering and siliqua formation was found beneficial for obtaining high seed yield, WUE as well as net returns.
\end{abstract}

\begin{tabular}{|l|}
\hline Ke y w o r d s \\
Hydrogel, Indian \\
mustard, Return, \\
Salicylic acid, \\
Water-use \\
efficiency, Yield \\
\hline Article Info \\
\hline $\begin{array}{l}\text { Accepted: } \\
26 \text { April } 2020 \\
\text { Available Online: } \\
\text { 10 May } 2020\end{array}$ \\
\hline
\end{tabular}

\section{Introduction}

Rapeseed-mustard is the world's most widely cultivated oilseed crop. It is utilized in various forms especially edible oil by human beings in the country and is the most important rabi season oilseed crop of Rajasthan which is grown mostly under conserve moisture and irrigated conditions. Irrigation water is an important input for realizing high mustard productivity. It is becoming the most limiting factor for crop production in most of the south-east parts of Rajasthan where fallowmustard and urdbean-mustard (U-M) is the 
major cropping system. A majority of mustard growers of the area are showing their interest to change the old exiting cropping system and being shifted to diversified double cropping system of urdbean- mustard under chancing climatic situation of the area and is facing availability of life saving irrigation water shortage in irrigated area, and declining ground water table are challenges for food security (Hira, 2009). Balanced fertilizer use is not only the first requirement; rather it is a prerequisite for improving the efficiency of conventionally applied major nutrients and other secondary inputs which enhance the yield as well as quality of mustard.

Presently in south-eastern Rajasthan Indian mustard (Brassica juncea) is being grown on vertisols after harvest of urdbean without considering important production factor i.e. soil moisture and environmental stresses responsible for harvesting good yield. So under such areas, proper management practices should be followed in order to conserve moisture, removal environmental stress and to increase water holding capacity of the soil. The best possible solution to the above said problem is hydrogel and SA application.

Hydrogel is basically cross-linked a water absorbing polymer used to increase water holding capacity, increase water use efficiency, to reduce soil erosion and nutrient losses, and absorb the nutrients to gradually release them. Super absorbent polymers (SAP) hydrogel can swell to absorb large quantity of water lead to may practical application in agriculture for improving water retention of soils and gradually supply to plants.

Salicylic acid (SA) is a phenolic compound and natural constituent of plant (Nazar and Sareer, 2015). It is a natural plant hormone, has many effects on physiological processes, growth of plants and has also an important role in tolerance of some environmental stresses such as heat, salts and drought stress (Hayat et al., 2009).

SA enhanced drought tolerance in mustard, inhibition of ethylene synthesis under drought stress, also influencing proline metabolism and photosynthesis resulted in efficient translocation of metabolism toward sink. When the two chemicals were applied together there was an additive effect on growing plants since hydrogel improve soil moisture level and SA minimizes environmental stress simultaneously.

Therefore, the present study strongly admits the use of salicylic acid as foliar application not only increased total yields but also getting good quality oil as well. Hence this study was undertaken to evaluate effect of hydrogel and foliar spray of salicylic acid on growth, yield, quality and water use efficiency of Indian mustard in restricted irrigation condition of south-eastern Rajasthan.

\section{Materials and Methods}

A field experiment was conducted at Agricultural Research Station, Kota $\left(26^{\circ}\right.$ North latitude, $76^{\circ}-6^{\prime}$ East longitude and 260 $\mathrm{m}$ above mean sea level) during the rabi seasons of 2017-18, 2018-19 and 2019-20 to evaluate effective dose of hydrogel and salicylic acid for increasing the productivity, quality and water use efficiency of Indian mustard in Vertisol of S-E Rajasthan in restricted irrigation conditions.

Treatments comprised of different hydrogel application rate in soil and foliar spray of salicylic acid either alone or their combination. The total of 12 treatment combinations, viz. $\mathrm{T}_{1}$ : control, $\mathrm{T}_{2}$ : hydrogel $2.5 \mathrm{~kg} / \mathrm{ha}, \mathrm{T}_{3}$ : hydrogel $5 \mathrm{~kg} / \mathrm{ha}, \mathrm{T}_{4}$ : salicylic acid (SA) $100 \mathrm{ppm}$ at flowering and siliqua 
formation, $\mathrm{T}_{5}$ : SA $200 \mathrm{ppm}$ at flowering and siliqua formation, $\mathrm{T}_{6}$ : Hydrogel $2.5 \mathrm{~kg} / \mathrm{ha}+$ SA $100 \mathrm{ppm}$ at flowering and siliqua formation, $\mathrm{T}_{7}$ : Hydrogel $2.5 \mathrm{~kg} / \mathrm{ha}+\mathrm{SA} 200$ ppm at flowering and siliqua formation, $\mathrm{T}_{8}$ : Hydrogel $5 \mathrm{~kg} / \mathrm{ha}+\mathrm{SA} 100 \mathrm{ppm}$ at flowering and siliqua formation, $\mathrm{T}_{9}$ : Hydrogel $5 \mathrm{~kg} / \mathrm{ha}+$ SA $200 \mathrm{ppm}$ at flowering and siliqua formation, $\mathrm{T}_{10}$ : Two irrigation at preflowering and siliqua formation, $\mathrm{T}_{11}$ : Hydrogel $2.5 \mathrm{~kg} / \mathrm{ha}+\mathrm{SA} 100 \mathrm{ppm}$ at flowering and $\mathrm{T}_{12}$ : hydrogel $2.5 \mathrm{~kg} / \mathrm{ha}+\mathrm{SA}$ $200 \mathrm{ppm}$ at flowering were laid out in randomized block design with three replications.

The experimental soil was clay loam in texture having field capacity (28.50\%), moisture holding capacity $(49.50 \%)$ with a $\mathrm{pH}$ of 7.95 , medium in organic carbon $(0.51 \%)$, available nitrogen (285 kg/ha), phosphorus (40.5 kg/ha) and high in potassium (390 $\mathrm{kg} / \mathrm{ha})$ and low in sulphur $(8.85 \mathrm{~kg} / \mathrm{ha})$ contents.

Hydrogel developed by the Indian Agricultural Research Institute (IARI), New Delhi, was used in study and hydrogel crystal form mixed well in the phosphate fertilizer was drilled in planting furrows / root zone at the time of sowing. $5 \mathrm{~kg} / \mathrm{ha}$ seed of variety 'DRMRIJ 31' was used, planted at crop geometry of $30 \times 10 \mathrm{~cm}$ in respective years.

Uniform application of recommended dose of $\mathrm{N}, \mathrm{P}_{2} \mathrm{O}_{5}, \mathrm{~K}_{2} \mathrm{O}$ and sulphur (80:40:30:40 kg /ha) was applied. Full dose of $\mathrm{P}_{2} \mathrm{O}_{5}, \mathrm{~K}_{2} \mathrm{O}, \mathrm{S}$ and half $\mathrm{N}$ were applied as basal at planting and half dose of $\mathrm{N}$ was top-dressed at 40 days after planting of the crop in the form of urea, dia-ammonium phosphate, muriate of potash and bentonite sulphur pellet fertilizers, respectively. For prepare an aqueous solution of salicylic acid use small amount of ethanol to dissolve SA and then add it to water, then foliar pray of salicylic acid as per treatment were done at flowering and siliqua formation stage with the help of a knapsack sprayer fitted with holocone nozzle with a spray volume of 600 liters/ha. The gross plot size for each treatment was $6 \mathrm{~m} \times 3.6 \mathrm{~m}$ and net plot size was $5 \mathrm{~m} \times 2.7 \mathrm{~m}$. All the recommended agronomic practices were done throughout the crop season. The average annual rainfalls received during cropping period of three years were $965 \mathrm{~mm}$.

The crop was harvested every year manually at physiological maturity stage as per treatments. Initial and post-harvest soil samples during 3 years were collected from 0 $15 \mathrm{~cm}$ depth, dried processed and analyzed for oxidizable organic carbon, N, P, K, S and physic-chemical properties of soil using the standard procedures. Soil-moisture and wateruse efficiency (WUE) were computed by using standard formula.

Growth, yield attributes, seed yield, quality parameter and available nutrient uptake were workout as per standard statistical procedure and using formulae. Gross and net returns were calculated based on the seed and straw yield and prevailing market prices of mustard in respective seasons. The benefit: cost ratio was calculated by dividing the net returns from the total cost of cultivation. The data were statistically analysed and the results of pooled analysis are presented.

\section{Results and Discussion}

\section{Growth and yield attributes}

Application of hydrogel and salicylic acid and their combination had significant effect on growth and yield attributes over control. Among treatment combination of hydrogel and salicylic acid, significant improvement in plant height $(222.40 \mathrm{~cm})$ and dry matter/plant $(62.20 \mathrm{~g})$ were recorded under the application of hydrogel $5 \mathrm{~kg} / \mathrm{ha}+\mathrm{SA} 200 \mathrm{ppm}$ spray at 
flowering and siliqua formation over control $\left(\mathrm{T}_{1}\right)$, hydrogel $2.5 \mathrm{~kg} / \mathrm{ha}\left(\mathrm{T}_{2}\right)$ and hydrogel 5 $\mathrm{kg} / \mathrm{ha}\left(\mathrm{T}_{3}\right)$ and at par with rest of treatment combinations. Whereas, significantly higher branches/plant (16.13), siliquae/plant (236.67), seeds/ siliqua (16.23) and 1000-seed weight $(5.47 \mathrm{~g})$ recorded in same treatment combinations over control $\left(\mathrm{T}_{1}\right)$, hydrogel 2.5 $\mathrm{kg} / \mathrm{ha}\left(\mathrm{T}_{2}\right)$, hydrogel $5 \mathrm{~kg} / \mathrm{ha}\left(\mathrm{T}_{3}\right)$, salicylic acid (SA) $100 \mathrm{ppm}$ at flowering and siliqua formation $\left(\mathrm{T}_{4}\right)$ and SA $200 \mathrm{ppm}$ at flowering and siliqua formation $\left(\mathrm{T}_{5}\right)$ but statistically at par with the rest of treatments (Table 1).

Hence, application of hydrogel $5 \mathrm{~kg} / \mathrm{ha}+$ foliar spray of SA $200 \mathrm{ppm}$ at flowering and siliqua formation showed similar trend in growth and yield attributes as that of two irrigations at pre-flowering and siliqua formation.

Significantly higher yield attributes might be observed with develop congenial environment in soil due to application of hydrogel which improved soil-moisture conditions and thereby increased the uptake of nutrients by crop. This might be owing to fact that hydrogel improved the soil-moisture conditions in addition to reducing the leaching losses of nutrients.

Similar findings were also reported by Rehman et al., (2011) on rice, Das et al., (2013) on sorghum and Dar and Hariram (2016) in wheat. Uniform application of NPK levels with hydrogel created better nutritional environment in soil system resulting in brought significant improvement in seeds/siliqua and test weight.

These results are in agreement to Mady (2007) in tomato and Hayat et al., (2009) in mustard. Furthermore, SA showed synergetic effect when sprayed two times promoted flowering in combination with other natural plant hormone (Tirani et al., 2013).

\section{Yield and quality}

Seed and stover yield (2651.89 and 5515.93 $\mathrm{kg} / \mathrm{ha})$, oil content $(38.95 \%)$ and oil yield $(1032.91 \mathrm{~kg} / \mathrm{ha})$ recorded under application of hydrogel $5 \mathrm{~kg} / \mathrm{ha}+$ two spray of salicylic acid $200 \mathrm{ppm}$ at flowering and siliqua formation were significantly higher than hydrogel and SA alone application levels $\left(\mathrm{T}_{1}, \mathrm{~T}_{2}, \mathrm{~T}_{3}, \mathrm{~T}_{4}\right.$, and $\mathrm{T}_{5}$ ) except two irrigations treatment and at par with rest of treatments (Table 2).

Whereas the highest harvest index $(32.47 \%)$ and protein content $(21.07 \%)$ was obtained under the same treatment which was significantly better than only control but statistically at par with all the other treatments. The increase in seed yield might be attributed to higher number of yield attributes, viz. branches/plant, siliquae/plant, seeds/siliqua and 1000-seed weight.

This could be due to application of hydrogel in soil + foliar spay of salicylic acid improving soil moisture conditions and water supply of plants, reduce drought impact on plants leading to reduced stress and oxygen radical formation and thus increasing the absorption of plant nutrients resulted in provides better scope for better growth and yield even in unfavourable climatic conditions.

Application of hydrogel and salicylic acid and their combination created better nutritional environment in soil as well plant system resulting in brought significant improvement in oil and protein content in seed. The inhibition of ethylene synthesis under stress condition might be owing to foliar spray of SA 200 ppm resulted in influencing proline metabolism and photosynthesis ultimately improved superiority of Indian mustard seems to be on a account of efficient translocation of metabolism toward sink. This could be owing to the higher moisture availability, reduced 
leaching losses and also minimise environmental stress under hydrogel and foliar spray of salicylic acid application.

Further, foliar spray of SA 200 ppm at flowering and siliqua formation stages created better nutritional environment in soil plant system resulted in minimise environmental stress i.e. temperature and drought stress which ultimately enhanced all the growth and yield attributes of crop coupled with increase in physiological processes and efficient translocation of photosynthates towards reproductive organs which reflected in higher seed yield of mustard.

Our results confirm the findings of Ekebafe et al., (2011), Kaur et.al. (2015), Saini et al., (2016), Dar and Hariram (2016), Godara et al., (2016), Jat et al., (2018) and Neethu et al., (2018).

\section{Economics}

The economic analysis of the crop revealed that gross return and net returns was influenced significantly by various treatment of hydrogel with foliar spray of salicylic acid and irrigations treatment but benefit cost ratio was statistically on par in all the other treatments except irrigation levels. There were differences in cost of cultivation and net return owing to different treatment cost (Table 3).

The highest gross and net return ( $₹ 1,18,086$ and 91,636/ha) recorded under the application of two irrigations at pre-flowering and siliqua formation stage followed by application of hydrogel $5 \mathrm{~kg} / \mathrm{ha}$ with two spray of salicylic acid $200 \mathrm{ppm}$ at flowering and siliqua formation was significantly better than all the other treatments and statistically at par with hydrogel with $\mathrm{SA}\left(\mathrm{T}_{6}, \mathrm{~T}_{7}, \mathrm{~T}_{8}\right.$ and $\left.\mathrm{T}_{9}\right)$ treatments. While benefit cost ratio of 3.46 recorded in the same treatment was significantly higher than all the other treatments. However, the rate of increase in net return was very less by application of hydrogel and SA at lower levels either alone or their combination, indicating the nonresponsiveness and the non-suitability of this treatment for increasing mustard production.

Maximum production cost (₹30,586 /ha) recorded in hydrogel $5 \mathrm{~kg} / \mathrm{ha}+$ two spray of salicylic acid $200 \mathrm{ppm}$ at flowering and siliqua formation owing to higher cost of hydrogel, whereas minimum production cost (₹25,250/ha) and net return (₹67,555/ha) recorded in control. The results confirm the finding of Kaur et.al., (2015).

\section{Water-use efficiency}

Among hydrogel and salicylic acid treatments, the water-use efficiency (12.83 $\mathrm{kg} / \mathrm{ha}-\mathrm{mm}$ ) was significantly higher under application of hydrogel $5 \mathrm{~kg} / \mathrm{ha}+$ two spray of salicylic acid $200 \mathrm{ppm}$ at flowering and siliqua formation than all other hydrogel and salicylic acid alone application levels $\left(\mathrm{T}_{1}, \mathrm{~T}_{2}\right.$, $\mathrm{T}_{3}, \mathrm{~T}_{4}$, and $\mathrm{T}_{5}$ ) and two irrigations treatment and at par with rest of treatments (Table 3 ).

The lowest water use efficiency $(7.33 \mathrm{~kg} / \mathrm{ha}$ $\mathrm{mm}$ ) was recorded under two irrigations treatment, while the highest soil moisture retention $(17.89 \%)$ recorded in two irrigations treatment was significantly higher than all the other treatments due to more conservative water availability and the lowest soil moisture $(11.87 \%)$ was recorded in control.

This was mainly due to lower soil moisture retention and water storage in the root zone depth at later stage which indicates no efficient water use under two irrigations. Furthermore this indicates the beneficial role of hydrogel in saving the irrigation water available in limited water supply conditions. 
Table.1 Effect of hydrogel and salicylic acid on growth and yield attributes of Indian mustard (Pooled data of 3 years)

\begin{tabular}{|c|c|c|c|c|c|c|}
\hline Treatment & $\begin{array}{l}\text { Plant height } \\
\text { (cm) at harvest }\end{array}$ & $\begin{array}{l}\text { Dry matter } \\
\text { /plant (g/) } \\
\text { at harvest }\end{array}$ & $\begin{array}{l}\text { Branches } \\
\text { / plant }\end{array}$ & $\begin{array}{l}\text { Siliquae } \\
\text { / plant }\end{array}$ & $\begin{array}{l}\text { Seeds / } \\
\text { siliqua }\end{array}$ & $\begin{array}{l}\text { 1000-seed } \\
\text { weight }(g)\end{array}$ \\
\hline T1: Control & 210.00 & 48.50 & 11.91 & 152.67 & 14.23 & 4.69 \\
\hline T2: Hydrogel 2.5 kg/ha & 213.50 & 54.20 & 14.44 & 185.45 & 15.21 & 4.80 \\
\hline T3: Hydrogel 5 kg/ha & 216.00 & 56.00 & 15.26 & 193.34 & 15.35 & 4.94 \\
\hline $\begin{array}{l}\text { T4: Salicylic acid } 100 \text { ppm at flowering and siliqua } \\
\text { formation }\end{array}$ & 217.00 & 57.60 & 13.95 & 180.00 & 15.02 & 5.03 \\
\hline $\begin{array}{l}\text { T5: Salicylic acid } 200 \text { ppm at flowering and siliqua } \\
\text { formation }\end{array}$ & 217.50 & 58.10 & 14.09 & 186.78 & 15.05 & 5.12 \\
\hline $\begin{array}{l}\text { T6: Hydrogel } 2.5 \mathrm{~kg} / \mathrm{ha}+\text { Salicylic acid } 100 \mathrm{ppm} \text { at } \\
\text { flowering and siliqua formation }\end{array}$ & 218.00 & 59.50 & 15.05 & 213.45 & 15.51 & 5.28 \\
\hline $\begin{array}{l}\text { T7: Hydrogel } 2.5 \mathrm{~kg} / \mathrm{ha}+\text { Salicylic acid } 200 \mathrm{ppm} \text { at } \\
\text { flowering and siliqua formation }\end{array}$ & 220.10 & 60.00 & 15.34 & 217.89 & 15.61 & 5.34 \\
\hline $\begin{array}{l}\text { T8: Hydrogel } 5 \mathrm{~kg} / \mathrm{ha}+\text { Salicylic acid } 100 \mathrm{ppm} \text { at } \\
\text { flowering and siliqua formation }\end{array}$ & 220.70 & 61.10 & 15.85 & 225.49 & 15.97 & 5.42 \\
\hline $\begin{array}{l}\text { T9: Hydrogel } 5 \mathrm{~kg} / \mathrm{ha}+\text { Salicylic acid } 200 \mathrm{ppm} \text { at } \\
\text { flowering and siliqua formation }\end{array}$ & 222.40 & 62.20 & 16.33 & 236.67 & 16.23 & 5.47 \\
\hline $\begin{array}{l}\text { T10:Two irrigations at pre-flowering and siliqua } \\
\text { formation }\end{array}$ & 223.00 & 63.00 & 16.75 & 241.18 & 16.52 & 5.55 \\
\hline $\begin{array}{l}\text { T11: Hydrogel } 2.5 \mathrm{~kg} / \mathrm{ha}+\text { Salicylic acid } 100 \mathrm{ppm} \text { at } \\
\text { flowering }\end{array}$ & 216.00 & 59.00 & 14.90 & 207.70 & 15.36 & 5.20 \\
\hline $\begin{array}{l}\text { T12: Hydrogel } 2.5 \mathrm{~kg} / \mathrm{ha}+\text { Salicylic acid } 200 \mathrm{ppm} \text { at } \\
\text { flowering }\end{array}$ & 218.50 & 60.40 & 15.18 & 215.71 & 15.42 & 5.25 \\
\hline SEm \pm & 2.12 & 1.82 & 0.64 & 7.71 & 0.36 & 0.14 \\
\hline CD $(0.05 \%)$ & 6.20 & 5.40 & 1.81 & 21.74 & 1.00 & 0.40 \\
\hline
\end{tabular}


Table.2 Effect of hydrogel and salicylic acid on seed yield and quality of Indian mustard (Pooled data of 3 years)

\begin{tabular}{|c|c|c|c|c|c|c|}
\hline Treatment & Seed yield (kg/ha) & $\begin{array}{c}\text { Stover } \\
\text { yield } \\
\text { (kg/ha) }\end{array}$ & $\begin{array}{c}\text { Harvest } \\
\text { index }(\%)\end{array}$ & $\begin{array}{l}\text { Oil content } \\
(\%)\end{array}$ & $\begin{array}{l}\text { Oil yield } \\
\text { (kg / ha) }\end{array}$ & $\begin{array}{c}\text { Protein } \\
\text { content } \\
(\%)\end{array}$ \\
\hline T1: Control & 2160.20 & 4493.22 & 32.12 & 38.00 & 820.88 & 20.80 \\
\hline T2: Hydrogel $2.5 \mathrm{~kg} / \mathrm{ha}$ & 2242.89 & 4665.13 & 32.36 & 38.30 & 859.03 & 20.86 \\
\hline T3: Hydrogel 5 kg/ha & 2304.52 & 4793.33 & 32.47 & 38.35 & 883.78 & 20.90 \\
\hline $\begin{array}{l}\text { T4: Salicylic acid } 100 \mathrm{ppm} \text { at flowering and siliqua } \\
\text { formation }\end{array}$ & 2205.50 & 4587.37 & 32.43 & 38.50 & 849.12 & 20.95 \\
\hline $\begin{array}{l}\text { T5: Salicylic acid } 200 \mathrm{ppm} \text { at flowering and siliqua } \\
\text { formation }\end{array}$ & 2242.29 & 4663.95 & 32.44 & 38.58 & 865.08 & 20.96 \\
\hline $\begin{array}{l}\text { T6: Hydrogel } 2.5 \mathrm{~kg} / \mathrm{ha}+\text { Salicylic acid } 100 \mathrm{ppm} \text { at } \\
\text { flowering and siliqua formation }\end{array}$ & 2439.10 & 5073.33 & 32.45 & 38.65 & 942.71 & 21.00 \\
\hline $\begin{array}{l}\text { T7: Hydrogel } 2.5 \mathrm{~kg} / \mathrm{ha}+\text { Salicylic acid } 200 \mathrm{ppm} \text { at } \\
\text { flowering and siliqua formation }\end{array}$ & 2514.66 & 5230.49 & 32.46 & 38.75 & 974.43 & 21.02 \\
\hline $\begin{array}{l}\text { T8: Hydrogel } 5 \mathrm{~kg} / \mathrm{ha}+\text { Salicylic acid } 100 \mathrm{ppm} \text { at } \\
\text { flowering and siliqua formation }\end{array}$ & 2613.57 & 5436.22 & 32.46 & 38.80 & 1014.07 & 21.05 \\
\hline $\begin{array}{l}\text { T9: Hydrogel } 5 \mathrm{~kg} / \mathrm{ha}+\text { Salicylic acid } 200 \mathrm{ppm} \text { at } \\
\text { flowering and siliqua formation }\end{array}$ & 2651.89 & 5515.93 & 32.47 & 38.95 & 1032.91 & 21.07 \\
\hline $\begin{array}{l}\text { T10: Two irrigations at pre-flowering and siliqua } \\
\text { formation }\end{array}$ & 2763.29 & 5736.47 & 32.50 & 39.00 & 1077.68 & 21.05 \\
\hline $\begin{array}{l}\text { T11: Hydrogel } 2.5 \mathrm{~kg} / \mathrm{ha}+\text { Salicylic acid } 100 \mathrm{ppm} \text { at } \\
\text { flowering }\end{array}$ & 2357.83 & 4952.16 & 32.44 & 38.60 & 910.12 & 20.97 \\
\hline $\begin{array}{l}\text { T12: Hydrogel } 2.5 \mathrm{~kg} / \mathrm{ha}+\text { Salicylic acid } 200 \mathrm{ppm} \text { at } \\
\text { flowering }\end{array}$ & 2442.38 & 5088.36 & 32.45 & 38.65 & 943.98 & 21.01 \\
\hline SEm \pm & 118.65 & 229.27 & 0.08 & 0.14 & 48.74 & 0.10 \\
\hline CD $(0.05 \%)$ & 334.53 & 646.42 & 0.25 & 0.40 & 144.83 & 0.25 \\
\hline
\end{tabular}


Table.3 Economics, soil moisture available and water use efficiency of Indian mustard under different treatments (Pooled data of 3 years)

\begin{tabular}{|c|c|c|c|c|c|c|}
\hline Treatment & $\begin{array}{l}\text { Cost of cultivation } \\
\text { ( ₹/ha) }\end{array}$ & $\begin{array}{c}\text { Gross } \\
\text { returns } \\
\text { (₹/ ha) }\end{array}$ & $\begin{array}{c}\text { Net } \\
\text { returns } \\
\text { (₹/ ha) }\end{array}$ & $\begin{array}{l}\mathrm{B}: \mathrm{C} \\
\text { ratio }\end{array}$ & $\begin{array}{c}\text { Soil } \\
\text { moisture } \\
(\%) \text { at } 100 \\
\text { DAS }\end{array}$ & $\begin{array}{c}\text { WUE } \\
\text { (kg/ha- } \\
\text { mm) }\end{array}$ \\
\hline T1: Control & 25250 & 92805 & 67555 & 2.67 & 11.87 & 10.61 \\
\hline T2: Hydrogel $2.5 \mathrm{~kg} / \mathrm{ha}$ & 27750 & 96241 & 68491 & 2.47 & 12.40 & 10.92 \\
\hline T3: Hydrogel 5 kg/ha & 30250 & 98828 & 68578 & 2.27 & 12.59 & 11.20 \\
\hline $\begin{array}{l}\text { T4: Salicylic acid } 100 \mathrm{ppm} \text { at flowering and siliqua } \\
\text { formation }\end{array}$ & 25418 & 94733 & 69315 & 2.73 & 11.80 & 10.88 \\
\hline $\begin{array}{l}\text { T5: Salicylic acid } 200 \text { ppm at flowering and siliqua } \\
\text { formation }\end{array}$ & 25586 & 96300 & 70714 & 2.76 & 11.87 & 11.08 \\
\hline $\begin{array}{l}\text { T6: Hydrogel } 2.5 \mathrm{~kg} / \mathrm{ha}+\text { Salicylic acid } 100 \mathrm{ppm} \text { at } \\
\text { flowering and siliqua formation }\end{array}$ & 27918 & 104507 & 76589 & 2.74 & 12.70 & 11.90 \\
\hline $\begin{array}{l}\text { T7: Hydrogel } 2.5 \mathrm{~kg} / \mathrm{ha}+\text { Salicylic acid } 200 \mathrm{ppm} \text { at } \\
\text { flowering and siliqua formation }\end{array}$ & 28086 & 107712 & 79626 & 2.84 & 12.95 & 12.31 \\
\hline $\begin{array}{l}\text { T8: Hydrogel } 5 \mathrm{~kg} / \mathrm{ha}+\text { Salicylic acid } 100 \mathrm{ppm} \text { at } \\
\text { flowering and siliqua formation }\end{array}$ & 30418 & 111851 & 81436 & 2.68 & 13.54 & 12.79 \\
\hline $\begin{array}{l}\text { T9: Hydrogel } 5 \mathrm{~kg} / \mathrm{ha}+\text { Salicylic acid } 200 \mathrm{ppm} \text { at } \\
\text { flowering and siliqua formation }\end{array}$ & 30586 & 113404 & 82818 & 2.71 & 13.70 & 12.83 \\
\hline $\begin{array}{l}\text { T10:Two irrigations at pre-flowering and siliqua } \\
\text { formation }\end{array}$ & 26450 & 118086 & 91636 & 3.46 & 17.89 & 7.33 \\
\hline $\begin{array}{l}\text { T11: Hydrogel } 2.5 \mathrm{~kg} / \mathrm{ha}+\text { Salicylic acid } 100 \mathrm{ppm} \text { at } \\
\text { flowering }\end{array}$ & 27834 & 102069 & 74236 & 2.65 & 12.78 & 11.55 \\
\hline $\begin{array}{l}\text { T12: Hydrogel } 2.5 \mathrm{~kg} / \mathrm{ha}+\text { Salicylic acid } 200 \mathrm{ppm} \text { at } \\
\text { flowering }\end{array}$ & 27918 & 104886 & 76968 & 2.76 & 12.92 & 11.96 \\
\hline SEm \pm & - & 4830 & 4856 & 0.17 & 0.52 & 0.54 \\
\hline CD $(\overline{0.05 \%)}$ & - & 13619 & 13693 & 0.48 & 1.50 & 1.52 \\
\hline
\end{tabular}


Hydrogel application either 2.5 or $5 \mathrm{~kg} / \mathrm{ha}$ with two foliar spray of salicylic acid 200 ppm was found significant better than two irrigations treatment and control where no hydrogel was applied. WUE is the function of economic yield to amount of water used by the crop during its growing period. Henceforth hydrogel was found more effective under restricted irrigation conditions in vertisols. These results support the findings of EL-Hardy et al., (2009), Narjary et al., (2012) and Dar and Hariram an(2016) and Jat et al., (2018).

It can be concluded that application of hydrogel either at the rate of 2.5 or $5 \mathrm{~kg} / \mathrm{ha}$ with two foliar spray of salicylic acid 200 ppm at flowering and siliqua formation was found beneficial in saving the irrigation water and increasing water use efficiency, and irrigation levels could be restricted to 1 instead of 2 irrigations without reducing the yield of Indian mustard significantly in restricted irrigation conditions in vertisols of south- eastern Rajasthan.

\section{References}

Dar, S. B. and Hariram.2016. Grain yield, nutrient uptake and water-use efficiency of wheat (Triticum aestivum) under different moisture regimes, nutrient and hydrogel levels. Indian Journal of Agronomy 61 (1):101-104.

Dass, A., Singh, A. and Rana, D. S. 2013. Insitu moisture conservation and nutrient management practices in foddersorghum (Sorghum bicolour).Annals of Agricultural Research New Series 34 (4):254-259.

Ekebafe, L. O., Ogbeifun, D. E. and Okiemen, F. E. 2011. Effect of native cassava starch-poly (sodium acrylate-coacrylamide) hydrogel on the growth performance of maize (Zea mays) seedlings. Am. J. Polymer Sci., 1:6-11.
El-Hardy, O. A., El-Kader, A.A. and Shafi, A. M.2009. Physio-bio-chemical properties of the sandy soil conditioned with acrylamide hydrogels after cucumber plantation. Australian Journal of Basic and Applied Sciences 3:3145-3151.

Godara, O. P., Kakralya, B. L., Kumar, S., Kumar, V. and Singhal, R.K. 2016. Influence of sowing time, varieties and salicylic acid application on different physiological parameters of Indian mustard (Brassica juncea). Journal of Pure and Applied Microbiology 10 (4):1-5.

Hayat, S., Masood, A., Yusuf, M., Fariduddin, Q. and Ahmad, A.2009. Growth of Indian mustard in response to salicylic acid under high- temperature stress. Brazilian Journal of Plant Physiology 21 (2):20-25.

Hira, G. S.2009. Water management in northern states and the food security of India. Journal of Crop Improvement 23:136-157.

Jat, A., Rathore, B. S., Desai, A. G. and Shah, S. 2018. Production potential, water productivity and economics feasibility of Indian mustard (Brassica juncea) under deficit and adequate irrigation scheduling with hydrogel. Indian Journal of Agricultural Sciences 88 (1):211-215.

Kaur, J., Hariram, Gill, B.S. and Kaur,J.2015.Agronomic performance and economic analysis of soybean (Glycine max) in relation to growth regulating substances in Punjab, India. Indian Journal of Agricultural Research 49 (6):534-538.

Narjary, B., Agarwal, P., Singh, A., Chakraborty, D. and Singh, R. 2012. Water availability in different soils in relation to hydrogel application. Geoderma 187: 94-101.

Nazar, R. and Sareer, O. 2015.Salicylic acid and supplementation improves 
photosynthesis and growth in mustard through changes in proline accumulation and ethylene formation under drought stress. South African Journal of Botany 98: 84-94.

Neethu, T.M., Dubey, P.K. and Kaswala, A.R.2018.Prospects and Applications of Hydrogel Technology in Agriculture. International Journal of Current Microbiology and Applied Sciences 7 (5):3155-3162.

Mady, M. A. 2007. Effect of foliar application with salicylic acid and vitamin $\mathrm{E}$ on growth and productivity of tomato (Lycopersicon esculentum, Mill.) plant. Agric. Botany Dept., Fac. of Agric., Benha Univ., Egypt.

Meena, B.S. and Meena, D.S.2015.Comparative response of Indian mustard (Brassica juncea) to sulphur sources on vertisols of Rajasthan. Annals of Agricultural Research New Series 36 (1):1-7.

Rehman, A., Ahmad, R. And Safdar, M. 2011. Effect of hydrogel on the performance of aerobic rice sown under different techniques. Plant, Soil and Environment 57:321-325.

Saini, C., Jain, N.K. and Mathukia, R. K.2016.Effect of sulphur and plantgrowth regulators on growth, yield and economics of summer groundnut (Arachis hypogaea). Indian Journal of Agronomy 61(1):115-118.

Tirani,M. M., Nasibi, F. and Kalantari, F.H.M. 2013.Interaction of salicylic acid and ethylene and their effects on some physiological and biochemical parameters in canola plants (Brassica napus L.). Photosynthetica 51:411-418.

\section{How to cite this article:}

Meena. B. S., R. S. Narolia, L. K. Meena, K. C. Meena and Meena. S. N. 2020. Evaluation of Hydrogel and Salicylic Acid Application Effect on Yield, Quality, Economics and Water-Use Efficiency of Indian Mustard (Brassica juncea) in Restricted Irrigation Condition of S-E Rajasthan. Int.J.Curr.Microbiol.App.Sci. 9(05): 3274-3283.

doi: https://doi.org/10.20546/ijcmas.2020.905.388 